\title{
Juridical Analysis of The Authority of The Civil Services Police Unit In Enforcement of The Minister of Home Affairs Regulation No. 26 of 2005 (Study of Simalungun Regency)
}

\section{Delfin Mikhael Meliala}

Sumatera University Faculty Of Law. E-mail: delfinmeliala@gmail.com

\begin{tabular}{l} 
ARTICLE INFO \\
\hline Keywords: \\
Juridical Analysis, The Civil \\
Services Police Unit \\
Article history: \\
Received Feb 01, 2020; \\
Revised Mar 05, 2020; \\
Accepted Jun 15, 2020; \\
Online Jul 30, 2020. \\
\end{tabular}

\begin{abstract}
Policeman Guardian Territory Of Jurisdiction that is sets of Equipment Administration Territory in Keep and Execute Calm and Orderliness the public with cause Arrange Territory and Arrange Head Territory. So Squad Policeman Guardian Territory Of Jurisdiction that is sets of Administration in area Arrange Territory, orderlinnes the public, and Calm Society. Squad Policeman Guardian Territory Of Jurisdiction in lead by someone head squad and be in under and be responsible see Head Territory. In order that implementation of the duty Squad Policeman Guardian Territory Of Jurisdiction can power use and result use in best, need to be compass Operational as Procedure Permanent For Squad Policeman Guardian Territory Of Jurisdiction in bring about duty.Be then are become problems in research this form how duty stake and function Squad Policeman Guardian Territory Of Jurisdiction, how Squad Policeman Guardian Territory Of Jurisdiction upgrade professionalism, how compass Procedures Permanent Operational Squad Policeman Guardian Territory Of Jurisdiction. There is even principle research are in take deep research in wear encode for processing primary that is with make interview at side Squad Policeman Guardian Territory Of Jurisdiction of equipment Residence Simalungun with in add by literature with be related to by title and problem. At finish creation this in come together a certain conclusion are form distribution from answer problem are in take away according to brief and in give as well little suggestion at side are related to use go forward with input at rubber side for can in purpose carefully.
\end{abstract}

This is an open access article under the CC BY-NC license.

\section{Introduction}

Recently, the actions of the Civil Service Police Unit (SatPol PP) have never gone unnoticed by the public, considering that all of its activities are easily known through news coverage in the mass media, both print and electronic. Unfortunately, the views that are formed in the minds of the public on the actions of the SatPol PP apparatus are very far from an ideal figure, which actually describes local government officials who in carrying out their duties uphold legal norms, religious norms, human rights and other social norms that live and work. develop in society.

The appearance of a skewed image of the figure of the Civil Service Police (SatPol PP) is nothing but, because the public is often treated to repressive actions, but the regional apparatus seems arrogant when carrying out their role in maintaining and implementing security and public order. 
Demolition of illegal buildings, control of street vendors, sex workers and homeless people, which often lead to physical clashes, are everyday images that are often presented by SatPol PP officials, even though these repressive actions are only part of the function and role of SatPol $\mathrm{PP}$, as non-legal law enforcement bearers. judiciary in the area. Therefore, it is not an exaggeration if the public then labels the SatPol PP officers as rude, arrogant, oppressors of small communities, and other names that are not pleasant to hear.

Coupled with the role of the mass media which often embellish it with sensational news, the portrayal of SatPol PP becomes increasingly skewed. Regardless of whether the public's description of the SatPol PP is correct, in this paper I try to refresh our memory about the true function and role of the SatPol PP in the context of fostering security and law enforcement. This description is important to put forward in order to obtain common views, both from the community, SatPol PP, and other stakeholders regarding the true figure of SatPol PP.

In order for the implementation of the duties of the Civil Service Police Unit to be efficient and optimally effective, it is necessary to have operational guidelines as a permanent procedure for the Civil Service Police Unit in carrying out their duties. The guidelines for the operational procedures for the Civil Service Police Unit are regulated in the Minister of Home Affairs Regulation Number 26 of 2005.

Standard Operational Procedures for the Civil Service Police Unit are instructions for the Civil Service Police in carrying out the task of administering public peace and order as well as in the context of increasing public awareness of Regional Regulations and Regional Head Regulations.

Based on the above background, in order to carry out the final task, the author sets the title: "Juridical Analysis of the Authority of the Civil Service Police Unit in Enforcement of the Regulation of the Minister of Home Affairs No. 26 of 2005 (Study of Simalungun Regency)".

\section{Method}

Materials or research materials used in this research is to conduct research on legal materials sourced from primary data by conducting research in the field and secondary data obtained from library research.

a. Primary legal materials are research materials or materials obtained during field research in the form of interviews, research on research objects directly in the field and various legal findings or facts that have occurred or were made during the course of the research.

b. Secondary legal materials, collection of legal materials related to research materials. This secondary legal material can be obtained by conducting a study and discussion of various literatures related to the material and object of research.

c. Tertiary legal material, is a method of collecting data sourced from various media such as Government Regulations, magazines, newspapers, tabloids or other sources deemed appropriate and related to research materials.

The type of analysis used in this study includes quantitative analysis, namely analyzing the results of research with a description of sentences so that they can solve problems.

\section{Analysis and Results.}

\subsection{The Civil Service Police Unit in Increasing Its Professionalisme}

a. Image of the Civil Service Police Unit 
The implementation of the functions of the SatPol PP in the field has always been a hot topic to discuss, this is because the SatPol PP is a line element that is always at the forefront of maintaining the mandate of Regional Regulations and is always in direct contact with the community. Reports about evictions, taking action against Persons with Social Welfare Problems (PMKS) and Beggars, Homeless and Abandoned People (PGOT) in the field always end in the formation of negative opinions. to the weak party without paying attention to the problem. This condition must of course be corrected and carefully observed by the parties concerned.

\section{b. Direction Policy which taken Ministry In Country towards the Guidance of Satpol PP}

The Ministry of Home Affairs through the Directorate of Civil Service Police and Linmas at the Directorate General of Public Administration as the general supervisor of the SatPol PP has anticipated to deal with the unbalanced news by making improvements to support the implementation of the activities of the SatPol PP, including:

1) Fixing the SatPol PP Institutions, will soon issue a Permendagri regarding Organizational Structure and Work Procedures (SOTK) in Province, Regency / City as well as Organizational Structure and Work Procedures

specifically for DKI Jakarta Province which is currently in the process of being at the Ministry of PAN and RB.

2) In terms of human resources, SatPol PP has Permendagri number 38 of 2010 concerning SatPol PP Training.

3) Meanwhile, in the field of budgeting, the Ministry of Home Affairs has issued several directives related to the synergy of the two pillars, namely the Ministry of Home Affairs with Regional Heads and DPRD with Provincial, Regency and City Heads. This is expected to increase knowledge about the main tasks and functions of SatPol PP, especially in increasing Regional Original Income (PAD) so that the existence of SatPol PP in the field can be further increased so that SatPol PP is no longer limited to only post guards or front officers during community demonstrations.

\section{c. Efforts to Increase the Professionalism of the Civil Service Police Unit}

In carrying out their duties, in the context of fostering and enforcing the law, the Civil Service Police are expected to always display professional performance, especially in facing developments in global conditions and challenges. Therefore, all SatPol PP officers are expected to be reliable officers and have clear thinking abilities, as well as excellent health and physical abilities to support success in their duties in the field.

But more importantly, of course, every SatPol PP apparatus must try to place the function of guidance to the community compared to law enforcement. This is important as a preventive effort so that the public is aware of the law (perda) and understands the importance of peace and public order, considering there is a tendency when law enforcement is emphasized, there is a potential for conflict to occur.

\subsection{Procedure Guidelines For Operational Procedures (Protap) Of Pamong Praja Police Units \\ a. General Understanding}

Public peace and order is a dynamic condition that allows the Government, Regional Government and the community to carry out their activities in a peaceful, orderly and orderly manner. To support the implementation of sustainable development in the region, Public Order and Order is a basic need in carrying out public welfare services. 0

1) Function :

a) Program preparation and implementation of public peace and order, enforcement of Regional Regulations and Regional Head Regulations. 
b) Implementation of policies for the maintenance and implementation of public peace and order in the Regions.

c) Implementation of policies for enforcement of Regional Regulations and Regional Head Regulations.

d) Implementation of coordination of maintenance and implementation of public peace and order, enforcement of Regional Regulations, Regional Head Regulations with State Police officers.

Investigation of Civil Servants (PPNS) and or other apparatus.

2) Authority:

a) To discipline and take action against members of the public or legal entities that disturb public peace and order.

b) Conduct examinations on community members or legal entities that violate Regional Regulations and Regional Head Regulations.

c) Carry out non-judicial repressive actions against community members or legal entities that violate Regional Regulations and Regional Head Regulations.

3) Obligation :

a) Uphold legal norms, religious norms, and human rights and other social norms that live and develop in society.

b) Help resolve community disputes that can disturb public peace and order.

c) Reporting to the State Police on the discovery or suspicion of a criminal act which is a violation or crime.

d) Submit toPPNS on the discovery or suspicion of violations of Regional Regulations and Regional Head Regulations.

b. Purpose, Goals and Goals

1) Meaning

The purpose of preparing the Operational Procedures for the Civil Service Police Unit is to serve as a guide for the Civil Service Police in carrying out the task of maintaining peace and public order and increasing public compliance and obedience to Regional Regulations and Regional Head Regulations.

2) Aim

The purpose of preparing the Operational Procedures for the Civil Service Police Unit is for uniformity in the implementation of the duties of the Civil Service Police in the administration of peace and public order and the enforcement of Regional Regulations and Regional Head Regulations.

3) Target

The creation of peace and public order as well as possible.

c. Standard Operational Procedures for the Civil Service Police Unit

Implementation Terms

1) General

The requirements that must be owned by every officer who fosters public peace and order are:

a) Every officer must have insight and knowledge about the basics of coaching/counseling, especially knowledge of various forms of Regional Regulations and other laws and regulations.

b) Can convey intent and purpose in good and correct Indonesian, can also be in the local language.

c) Mastering information delivery techniques and good presentation techniques.

d) Authoritative, full of confidence and high responsibility.

e) Every officer must be able to attract public sympathy. 
f) Able to accept suggestions and criticism from the public, especially the Civil Service Police Unit and to the Regional Government in general and able to identify problems, can also provide alternative solutions to problems without reducing their main tasks.

g) Officers who foster peace and public order must have the following characteristics:

2) Special. Knowledgebase which must owned by officer builder Public Peace and Order are:

a) Knowledge of the main tasks of the Civil Service Police in particular and Regional Government in general.

b) Knowledge of the basics of law and legislation.

c) Know the legal basics of carrying out the duties of the Civil Service Police.

d) Know the basics of communication science.

e) Understanding and mastering the customs and habits that apply in the Region.

f) Understanding and mastering as well as being able to read situations that have the potential to disrupt the conditions of peace and public order in the Region, both in the economic, political, socio-cultural and religious fields.

d. Equipment and Equipment

1) Task Order.

2) Clothing equipment used.

3) Operational Vehicles (patrol cars and lighting cars) equipped with loudspeakers and siren lights.

4) Two-wheeled vehicles to provide guidance and control to community members who are designated as targets whose locations are difficult to reach by four-wheeled vehicles.

5) First Aid Equipment in Accidents (P3K).

6) Personal protective equipment such as field hats/helmets and clubs.

7) Other equipment that supports the smooth development of peace and public order.

e. Stages, Forms and Methods of Implementation

One way of fostering public peace and order is the socialization of legal products, especially regional regulations, regional head regulations and other legal products in running the wheels of government in the regions to the public. This cannot be carried out all at once but is gradual and continuous, so that the public will understand the importance of obedience and compliance with local legal products.

The forms and methods in the framework of fostering peace and public order can be carried out in 2 (two) ways, namely:

1) Individual goals

a) Coaching is carried out by visiting community members who have been designated as targets to provide direction and appeal to the importance of obedience to Regional Regulations, Regional Head Regulations and other legal products.

b) Inviting/summoning members of the public whose actions have violated the provisions of Regional Regulations, Regional Head Regulations and other legal products to provide direction and guidance that the actions that have been carried out have disrupted public peace and order in the community in general.

2) Group Target. The development of public peace and order is carried out with the support of facilities from the Regional Government by presenting the community in a meeting building that is set as the target and resource persons discussing the importance of increasing obedience and compliance with Regional Regulations, Regional Head Regulations and other legal products in order to maintain public peace and order.

Technical Operations for the Guidance of Public Peace and Order in carrying out their duties:

1) Before heading to the target location, the appointed officer first gets directions and instructions about the aims and objectives of the Government which includes alternative problem solving from the leadership. 
2) Prepare and check all the needs and equipment and equipment that must be brought.

3) Each officer who is ordered must be equipped with a warrant of duty.

4) Mastering and understanding Regional Regulations, Regional Head Regulations and other legal products as well as targeted areas before coaching is carried out.

f. Orderly Development of Government

1) Carry out picket in turns.

2) Providing Guidance and Supervision of Office Security.

3) Provide/facilitate Guidance and Supervision as well as establish the implementation of Siskamling for Villages and Sub-districts.

4) Providing Guidance and Supervision of Regional Order Administration.

5) Carry out Supervision and Monitoring Visits in the context of fostering the implementation of Regional Regulations, Regional Head Regulations and other legal products.

6) Provide security against businesses/activities carried out en masse, to prevent disturbances to public peace and order.

7) Carry out efforts and activities to prevent crime.

8) Conduct inspections of Unlicensed Buildings, places of business and carry out enforcement.

9) Carry out business and activities in order to resolve disputes in the community.

10) Carry out various sectoral businesses and activities.

g. Environmental Order Management

1) Provide Guidance and Supervision of the extraction of stone sand in the context of environmental conservation.

2) Provide Guidance and Supervision regarding waste control and management, Environmental Hygiene with the target of community activity centers such as markets.

3) Provide Guidance and Supervision of businesses and activities that rely on the environment to produce production goods.

4) Carry out natural disaster management efforts and activities. ${ }^{26}$

h. Social Order Development

Doing business activities:

1) Prevention through counseling, guidance, training, providing supervision assistance and guidance to individuals and community groups that are estimated to be the source of the emergence of homeless people, beggars and WTS.

2) Repressive through raids, temporary shelters to reduce homeless people, beggars and WTS both to individuals and community groups suspected of being homeless, beggars and WTS.

3) Rehabilitation includes shelter, arrangement, education, capacity restoration and distribution back to their hometowns to restore their role, as citizens of the community.

4) Carry out control so that market activities can run smoothly, safely, cleanly and orderly.

5) Monitor, provide motivation and supervision of shop stalls, restaurants that carry out their activities without being equipped with a business license.

6) Cooperating with related agencies/agencies and security forces and orderliness of land/parking areas.

7) Supervise and control the violators of Regional Regulations, Regional Head Regulations and other legal products.

8) Conducting guidance on increasing public awareness in paying taxes and levies determined by the Regional Government as well as carrying out business and activities in order to increase the target of local revenue revenue. 


\section{Conclusion}

The Main Duties of the Civil Service Police Unit (Satpol PP) in the Government Regulation of the Republic of Indonesia Number 6 of 2010 concerning the Civil Service Police Unit that the Main Tasks of the Satpol PP are: Enforcing Regional Regulations (Perda), Organizing public order and public peace, Community protection. Functions of the Civil Service Police Unit (Satpol PP):

a. Program preparation and implementation of regional regulations enforcement, implementation of public order and public peace as well as community protection

b. Implementation of the policy of Enforcement of Regional Regulations and Regional Head Regulations

c. Implementation of policies Implementing public order and public peace in the regions

d. Implementation of Community Protection policy.

e. Coordinating the enforcement of regional regulations and regional head regulations, public order and public peace with the Indonesian National Police, regional Civil Servant Investigators, and/or other apparatus.

f. Supervision of the community, apparatus, or legal entities in order to comply with and comply with Regional Regulations and Regional Head Regulations.

g. Carrying out other tasks assigned by the Regional Head.

To be able to produce a professional Sat Pol PP apparatus, especially in the context of realizing its role in fostering and enforcing the law, several efforts can be made, including:

a. Strengthening the insights, skills, and performance of Pol PP HR towards a figure of professionalism in carrying out their duties, one of which is by changing the recruitment and education system for Pol PP officers;

b. Each member of the Pol PP must be equipped with adequate tactical and technical skills and tactics of civil service. The aim is that the steps taken by Pol PP members in carrying out their roles are as much as possible to avoid deviant actions;

c. Evaluation of the pattern of approaches that have been applied so far to assess the level of effectiveness, as well as to minimize the possibility of deviations;

d. Establish clear and synergistic guidelines, directions, and authorities with related elements, so that an effective operational mechanism is established in realizing a conducive situation in the region; Cooperating with all security and order officers and other law enforcement officers in order to create a synergistic relationship, considering that some of the authorities attached to the Satpol PP are also attached to other institutions;

e. Cooperating with all elements of society in efforts to maintain public peace and order.

\section{References}

Adi, Kusno, 2009, Criminal Policy in Combating Narcotics Crime by Children, UMM Press, Malang.

Astuti MS, 2003, Child Criminal Law and Child Protection, State University of Malang, Malang.

Atmasasmita, Romli, 1983, The Problem of Juvenile Delinquency, Armico, Bandung.

Directorate General of Public Administration and Regional Autonomy, Ministry of Home Affairs, 1990, Civil Service Police, Jakarta.

Directorate General of Government Development and Directorate General of PUOD Ministry of Home Affairs, 1991, Development of Civil Service Police Unit, PT Pradnya Paramita, Jakarta.

Gosita, Arif, 1989, Child Protection Issues, Pesindo Academic, Jakarta. 
Set of Legislations for the Civil Service Police Unit (Satpol PP) and their Implementing Regulations, 2011, Focus Media, Bandung.

Kartono, Kartini, 1981, Psychic Disorders, Sinar Baru, Bandung. Report of the Head of the Civil Service Police Unit, 2011, Main Duties and Functions Civil service police Unit, Pematang Raya, Simalungun Regency.

Poerwadarminta WJS, 1976, General Indonesian Dictionary, Balai Pustaka, Batavia.

Soekanto, Soerjono, 1990, Police and Traffic (Analysis According to Sociology of Law), Mandar Maju, Bandung.

Regulation of the Minister of Home Affairs Number 2 of 1993 concerning the Development of Peace and Order in the Regions.

Regulation of the Minister of Home Affairs Number 26 of 2005 concerning Guidelines for Standard Operational Procedures for Civil Service Police Units.

Government Regulation Number 25 of 2000 concerning Government Authorities and Provincial Authorities as Autonomous Regions.

Government Regulation Number 6 of 2010 concerning Civil Service Police Units.

Law Number 5 of 1974 concerning the Principles of Government in the Regions

Law Number 32 of 2004 concerning Regional Government

http : // resources.unpad.ac.id/2013/02/27 http://www.ipdn.ac.id/2013/02/12

http : / /repository.usu.ac.id/2013/01/23 http://www.ditjenpum.go.id/2013/03/11

http://www.referencemakalah.com/2013/01/22

http: //pekalongankota.go.id/2013/01/21 http: //mazpram.blogspot.com/2013/04/14 